\title{
International Business Travel and Australia's Skills Endowment
}

\section{Massimiliano Tani}

I mmigration policies in Australia have historically focused on permanent settlement and the establishment of 'demand' policies able to attract desirable migrants. For example, currently, the government sets each year the target intake of immigrants using a point system favouring skilled young people. A typical reason for wanting to attract these migrants is that the benefits they generate for the host country over their working lives (for example, bringing with them capital, contributing to higher domestic consumption, and paying taxes) are larger than the cost incurred (for example, health care, income support). However, due to globalisation and advancements in transportation technology, skilled labour has become internationally more mobile and sought after, making the principle of, and traditional reason for, permanent resettlement increasingly anachronistic. To deal with the changed character of the international 'immigration market' for skilled labour, the government has shifted its focus towards new categories of desirable, though not necessarily permanent, migrants. Since 1996 there is a privileged system for skilled temporary workers, particularly for those seconded to or working on assignments in Australia (up to four years), and for foreign students applying for permanent residence. As noted by the Minister for Immigration, 'Short-term and long-term skilled temporary entry are ... undoubtedly the touchstone of migration's future and one of the principal determinants of the nation we will become' (Ruddock, 2000:257).

Among skilled temporary migrants, research attention has been so far devoted to those staying or leaving for a year or more (for example, Birrell, 2001; Hugo, 2003; Withers, 2003). In contrast, very little is known about those moving to and from Australia for reasons of work for periods of 12 months or less ('short-term'), despite their significant flows. The annual number of entries and exits for work purposes runs in the hundreds of thousands, but nothing is known about the occupational and personal characteristics of those involved, let alone the motivations of their travel. The Australian Bureau of Statistics (ABS) indicates that although all travellers to and from Australia are requested to fill in a landing card, only a few do so fully, and these constitute too small a number for useful statistical analyses. Interestingly, less than 20 per cent of short-term business visits can be attributed to people holding temporary business visa (categories 456 and 956). In 2002, for the first time, the Department of Immigration and Multicultural and Indigenous Affairs (DIMIA) published statistics on short-term business arrivals by visa categories. These show that in 2001-2 there were 93,555 temporary short-term business entries (DIMIA, 2002:Table 2.2) vis-à-vis the more

Massimiliano Tani is a Lecturer in the School of Business at the University of New South Wales at The Australian Defence Force Academy. 
than 540,000 entries for short-term business purposes (ABS, 3401.0:various issues). Can the people entering and exiting Australia each year for business purposes for less than 12 months be considered labour migrants? If so, what are their volume and patterns, and how have they evolved over time? Should Australia welcome or try to discourage these people' arrivals and departures?

This paper presents preliminary results from a project aimed at shedding light on international business travels, that is, trips for work purposes lasting less than 12 months. The paper is organised in three parts. The first discusses whether the international movement of business people can be considered as a form of labour migration. This discussion is carried out on the basis of the existing literature and a preliminary analysis of the Australian data. The second focuses on international air business travel, presenting a measure of its annual volumes as well as a description of its patterns and evolution over the past 25 years. This measure transforms the flow of international air business travellers into 'equivalent workers' in each year. The third offers some thoughts about the possible normative implications of the international flow of air business travellers. In particular, it is argued that international business travellers may enhance the stock of knowledge existing in Australia, and promote its prospects for economic growth. As a result, it may be in Australia's interest to pay more attention to business travellers, as they might be a substitute for skilled permanent migration, though they might not contribute as much to Australia's domestic expenditure and taxation revenue.

\section{Is International Air Business Travel a Form of Labour Migration?}

International business travel is not new, though the literature on this phenomenon is very limited, perhaps reflecting the difficulty in measuring the flow of travellers. Even when this is technically feasible, as is the case for air travel, access to the data is limited by commercial sensitivity and cost. Despite the small number, existing studies concur in suggesting that the spread of international business travel follows improvements in communication and transportation technologies. For example, the arrival of steamships made it possible for thousands of Europeans in the late $18^{\text {th }}$ and early $19^{\text {th }}$ century to take advantage of farming jobs in Argentina and Brazil during the harvest season, exploiting opposite seasonal patterns in the Northern and Southern hemispheres (for example, Piore, 1979; Gould, 1980). More recently, air transport has allowed people to travel faster and further around the globe, enabling them to get to work in far away destinations in a matter of hours.

The typology of international business travel is wide, as it includes different modes and means of travel. Commuting, seasonal work and the business trips of company executives, movie stars, policymakers, academics and consultants among others are all forms of work-related international travel, which can be carried out by car, bus, train, and aeroplane. While it is generally accepted that commuting and seasonal work are forms of labour migration (for example, OECD, 1994), it is more difficult to do so readily in the case of occasional business trips abroad, 
because of a general lack of information on the purpose of travel. A few studies suggest that business trips are a form of labour migration, though they generally confine their analysis to international air business travel, as it represents the most common means for trips beyond a certain distance or to countries separated by natural barriers, as in the case of Australia, or the United Kingdom.

A key feature of international air business travel is that its users are almost exclusively highly skilled workers. For example, a survey carried out in 1988 reveals that more than 95 per cent of air business travellers in the largest eight member states of the European Union were senior managers, entrepreneurs and professionals (International Air Traveller Survey, 1988). A similar result emerges in the case of the US (Anderson, 2002). Within the studies in this literature, Salt (1992) suggests that large multinational companies commonly use business trips to transfer skills and experience from the headquarters to an overseas subsidiary. He further adds that with the globalisation of markets firms have been increasingly substituting skilled workers' relocations and short-term assignments abroad (two accepted forms of international labour migration) with frequent air business trips. This trend, particularly among skilled labour, is also documented by the business literature (for example, Ohmae, 1990; Sassen, 1991; Moss Kanter, 1995). Furthermore, the literature has suggested that the transfer of skills taking place through international air business travel occurs mainly across separately owned firms and not only within multinationals (for example, see the literature cited in Wood, 2001).

The view that air business travel is not a form of labour migration is generally based on two arguments. The first is that air business trips provide ancillary services that facilitate the international exchange of goods (for example, accompanying exported goods), and hence they should be considered as a component of the international trade of commodities. If this were the case, then one would expect to find a significant relationship between the flows of business travellers to/from a country and the value of its imports and exports or its terms of trade. In particular, high volumes of business travellers ought to correspond to high values of commodity trading and be affected by a country's terms of trade, and vice-versa. The second argument is that air business travel is an international exchange of services. If this were true, then one would expect to find a significant link between the flows of air business travellers and the value of a country's imports and exports of services.

Although the literature supporting these hypotheses does not yet exist, preliminary tests of their implications are reported below. In particular, the net flows of air business travellers were correlated to the terms of trade, used as a measure of activity of Australia's commodity trading, and the value of the net trade of services reported in the current accounts, respectively. Two more variables were included in the analysis. The first is the value of Australia's net foreign liabilities (Australia's capital account has historically been in surplus), accounting for the possibility that business travellers carry out transactions related to international movements of capital. The second is the unemployment rate, used as a measure of labour market activity, to account for the possibility that air 
business trips respond to labour market conditions, similarly to 'traditional' labour migration. In particular, one would expect to see lower volumes of incoming and outgoing business travellers if economic conditions in Australia deteriorate, and vice-versa. This simplistic structural model was estimated as:

$$
\begin{aligned}
& \mathrm{BT}_{\mathrm{t}}=\alpha+\beta\left({\text { commodity } \left.\text { trade }_{\mathrm{t}}\right)+\delta\left(\text { trade in services }_{\mathrm{t}}\right)+\varphi(\text { net foreign liabilities }}_{\mathrm{t}}\right)+ \\
& \gamma\left(\text { labour market }_{\mathrm{t}}\right)+\lambda\left(\text { trend }_{\mathrm{t}}\right)+\varepsilon_{\mathrm{t}}
\end{aligned}
$$

where $\mathrm{BT}_{\mathrm{t}}$ indicates the net volume of business travellers in 'equivalent workers' (EW) at time $t$ (see below), $\alpha$ is a constant, $\beta, \delta, \varphi, \gamma$, and $\lambda$ are parameters, and $\varepsilon$ is an error term. The EW is calculated as the difference of the product of the annual gross volume of in- and out-bound travellers and the average length of their respective stay, divided by the average number of working days in a year, which is set at 250. This measure is commonly used in the literature (for example, Anderson, 2002). The EW is independent of whether few travellers make multiple trips or many travellers make only one trip each year, as the result is identical. For example, a person travelling abroad for two days 30 times a year and 60 people travelling for a day only once in a year would have identical EWs of 60/250.

Under the null hypothesis that international air travel is part of commodity trade, the trade of services or international capital flows but not related to Australia's labour market, one would expect the coefficients $\beta$, $\delta$, and/or $\varphi$ to be significantly, and $\gamma$ to be insignificantly, (statistically) different from zero.

Table 1 reports the results of this analysis. These results can only be illustrative rather than conclusive, as they are obtained from 25 annual observations. The significantly different coefficients reflect different units of measure, as no rescaling was applied (for example, transforming the original unit of measure in logarithms) since improvements in readability would have been accompanied by a more complicated interpretation of the coefficients.

Table 1: Regression Results of the Structural Model, 1976-2000.

\begin{tabular}{ccccc}
\hline Variable & $\begin{array}{c}\text { Commodity } \\
\text { trade } \\
\text { (terms of trade) }\end{array}$ & $\begin{array}{c}\text { Trade of } \\
\text { services } \\
\text { (net trade: } \mathbf{~} \text { ) }\end{array}$ & $\begin{array}{c}\text { Capital flows } \\
\text { (net foreign } \\
\text { liabilities: } \mathbf{~} \text { ) }\end{array}$ & $\begin{array}{c}\text { Labour market } \\
\text { (unemployment } \\
\text { rate: \%) }\end{array}$ \\
\hline Coefficient & -254.4 & .73 & -.21 & -205.567 \\
t-statistics & -3.02 & 0.76 & -2.49 & -4.49 \\
\hline Adjusted $R^{2}$ & .9062 & & & \\
$D W$ & 1.62 & & & \\
\hline
\end{tabular}

Sources: Air business travel: ABS (Overseas Arrivals and Departures - ABS 3401.0); Commodity trade and trade of services: ABS (Balance of Payments - ABS 5368.0); Unemployment rate: ABS (Labour - ABS 6105.0)

Despite the few observations, the arguments suggesting that air business travel is not related to labour market conditions is statistically rejected, as shown by the highly significant t-statistics of -4.49 in the fourth column, which is the highest value among those reported in Table 1 (this result holds even after a 
logarithm transformation of the data). At the same time, business trips are statistically significantly correlated with commodity trade and movements of capital (t-statistics of -3.02 and -2.49 , respectively), but not with the trade of services (t-statistics of 0.76 ). These results suggest that international air business travel is linked to commodity trade and the flows of capital as well as the labour market of the host country, legitimising the view that international air business travel is a form of labour migration.

\section{International Air Business Travel: A Brief Summary}

The ABS collects data on air business travellers through the landing cards filled in on departure from and arrival to Australia, and published annually these data in the publication Overseas Arrivals and Departures. The series used in this section cover the period between 1976 (the earliest year for which these data are available) and 2000, and refer exclusively to travel for business purposes. Virtually all the data on international business trips refer to air travel, as this is the fastest and most common mode of business trips to and from Australia. The data indicate that the gross outflow of Australian-resident workers has been larger than the gross inflow of foreign labour throughout the period, and that the length of stay of Australian-residents travelling overseas has been on average slightly higher than that of foreign labour visiting Australia (25 days versus 23).

To have a sense of business travels' magnitude in terms of annual labour supply, both gross in- and out-flows of business travellers are transformed into an equivalent number of workers in a year. The net $\mathrm{EW}$ is the difference between the EW of the in- and out-bound flows of business travellers. A negative net EW represents a net export of Australian-resident workers while a positive net EW indicates a net import of foreign labour. The net outflow is depicted in Figure 1.

Figure 1 shows that Australia has been a net exporter of labour throughout 1976-2000. During this period the volumes of in- and outflows of business travellers have risen considerably (in 2000 they were six times those of 1976), while the average length of stay for both arriving foreigners and departing Australian-resident labour has declined by about 25 per cent. In particular, the net outflow of Australian-resident labour overseas through business travel shows three distinct phases. In the first, covering the 1976-1988 period, the net outflow of business travellers has been relatively constant around 6,000 EW each year. This period is characterised by similar rises in the volume of both incoming and departing business travellers. In the second phase, between 1988 and 1993, the net outflow of Australian labour travelling overseas more than trebled to about $20,000 \mathrm{EW}$ per annum. The data show that this result is due to faster increases in the outflows of Australian-resident labour, particularly since 1988, relative to the growth of the inflows of foreign visiting workers. The third phase, from 1993 to 2000 , is characterised by a relatively stable net outflow of Australian-resident labour of about 20,000 EW per annum. This is due to rising volumes of incoming foreign business travellers relative to steadily growing outflows of Australianresident labour. 


\section{Figure 1: The Net Outflow of Labour Through International Business Travel from Australia, 1976-2000.}

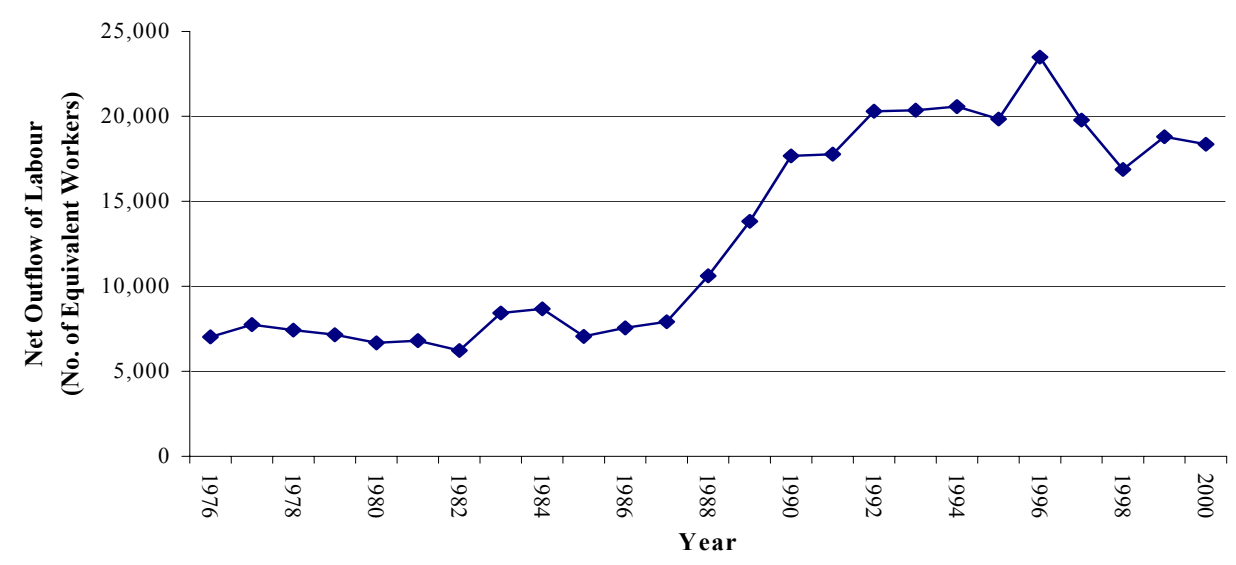

Source: ABS Overseas Arrivals and Departures (ABS 3401.0), various years

Throughout the period, the phases of international air business trips do not appear to reflect those followed by economic policy in Australia. Within each of the sub-periods identified above, fiscal and monetary policies have both been expansionary and restrictive, and followed shorter cycles. Fiscal policy was expansionary during 1982-1984 and 1991-1993, while it was restrictive in 19761982, 1984-1991 and 1993-96. Monetary policy was expansionary in 1979-1982, 1983-1986, and 1987-1990, and contractionary at the other times (Dornbush, Fisher and Kearney, 1995). Since the historic stance on either fiscal or monetary policy does not seem to shed any light on the phases of business travellers' net outflows, the search for possible explanations of the trend depicted in Figure 1 was directed towards Australia's underlying economic situation in the period. What seems to characterise the years between the late 1980s and the early 1990s is a general decline (sharp at first then smoother) in inflation in both Australia and internationally (after the rise caused by the oil shocks in the 1970s), and stable employment. The literature points to the floating of the Australian dollar in 1986, the success of the Accord in capping wage rises, and to higher labour productivity following microeconomic reforms, as Australian 'stand-out' events of that time (internationally, the stock market crash of October 1987 should also be mentioned). All these events concur to internationalise and increase the competitiveness of the Australian economy, hence offering potential explanations of the sharp increase in outbound business travel from Australia.

To gain further insight using existing data, the net outflow of business travellers was disaggregated by main area of destination. Four regions were identified: 
- English-speaking countries, with which Australia has strong historical and cultural connections (UK, USA, Canada, Ireland, South Africa, New Zealand);

- continental members of the European Union - that is, the part of the OECD that has contributed a significant amount of immigrants to Australia, particularly after WWII (Italy, France, the Benelux, Denmark, Germany, Greece, Spain and Portugal);

- ASEAN countries - that is, Australia's geographic neighbours;

- the rest of the world, which includes some of Australia's major trading partners such as China, South Korea, Hong Kong and Taiwan.

The net outflows of labour between Australia and these regions are summarised in Figure 2.

\section{Figure 2: Net Australian Labour Outflow through International} Business Travel by Region, 1976 - 2000.

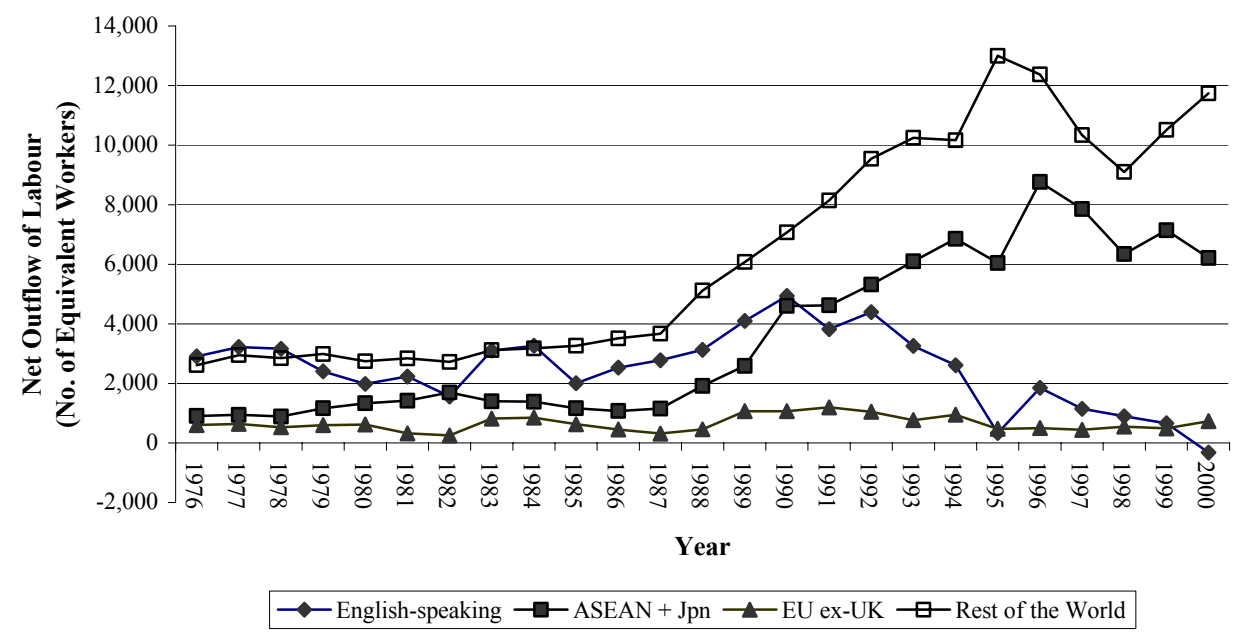

Source: ABS Overseas Arrivals and Departures (ABS 3401.0), various years

The patterns of business travellers reported in Figure 2 show significant variations, suggesting that underlying causes and motivations may differ across regions (see Table 2 below). Common to all cases was the growth in the volume of travellers throughout the period: both gross in- and outflows in 2000 were approximately six times as large as those recorded in 1976.

Business travel between Australia and other English-speaking countries accounts for almost half of total gross in- and outflows, though this proportion has declined in the period. In contrast, gross in- and outflows between Australia and ASEAN-Japan have been rising from 15 per cent to 25 per cent of total flows, while those between Australia and the rest of the world have remained about a 
third of total flows. Last and least, business travel between continental Europe and Australia has remained very small: it accounted for 10 per cent of total flows in 1976, but only 5 per cent in 2000.

Net outflows from Australia to member states of the European Union ex-UK have been remarkably stable throughout the period. The data indicate that both inand out-flows of business travellers have risen at similar rates over time, with minimal effect on the net outflow of Australian-resident labour, which stands at approximately $600 \mathrm{EW}$ per annum.

In contrast, the net outflow of business travellers to English-speaking countries has risen slightly between 1976 and 1990 but it has been declining thereafter to the extent that in 2000, for the first time, Australia has recorded a net inflow of labour from these geographic areas $(300 \mathrm{EW})$. This was due to the growth in the number of foreign business travellers, which has outstripped that of Australian-resident labour travelling in the opposite direction.

Against this scenario, the net outflow of business travellers towards ASEAN countries and Japan has been rising slowly until 1988 and sharply thereafter. A similar pattern arises in the case of business trips to/from the rest of the world, which includes some of Australia's major trading partners. In particular, between 1988 and 1996 Australian-resident labour travelling to both groups of countries has risen faster than the corresponding increase in the number of foreign businessmen and women travelling to Australia. Since 1996, the imbalance towards both ASEAN-Japan and the rest of the world has declined, and stabilised around a net outflow of 7,000 and 11,000 EW each year, respectively.

Figure 2 highlights that the sharp increase in the net outflows of business travellers of the late 1980s and early 1990s was due to the rising volume of Australian-based labour to nearby Asian countries, Japan and the rest of the world relative to that of Australian-bound flows. To search for a possible explanation, the regression performed on the total net outflow of EW from business travel was re-run using the net flows by geographic region as the dependent variable. The results, which are based on a small number of observations and thus should be viewed only as an illustration, are reported in Table 2.

Based on the statistical significance of the coefficients, the results shown in Table 2 suggest that business trips between Australia and ASEAN-Japan, and the rest of the world are related to movements of capital as well as labour market conditions in Australia, rather than exchanges of commodities and services. Labour market conditions in Australia (unemployment rate) appear to be the only common reason of business travel across all regions. While a labour market explanation of business trips to these regions is difficult without data on business travellers' motivations, it is possible to advance a tentative hypothesis for an explanation related to international capital flows. Since Australian investments in ASEAN-Japan and the rest of the world are only a very small proportion of Australia's total investments abroad (less than 10 per cent), the net outflows of business travel may be related to foreign investments from these regions to Australia. These regions tend to be net providers of capital. The sharp increase of Asian-bound business travel between 1988 and 1991 depicted in Figures 1 and 2 
could be linked to the 'discovery' of Australia as an investment destination from investors based in ASEAN-Japan and the rest of the world. This 'discovery' could have been activated by Australia's economic reforms (floating of the Australian dollar, the Accord, microeconomic reform), as well as by the need of higher risk diversification following the stock market crash of October 1987, which affected particularly investments in the US and Europe.

Table 2: Structural Model: Regression Results by Region 1976 - 2000.

\begin{tabular}{lrrrr}
\hline Variable & $\begin{array}{c}\text { ASEAN- } \\
\text { Japan }\end{array}$ & Rest of World & $\begin{array}{c}\text { English- } \\
\text { speaking }\end{array}$ & $\begin{array}{c}\text { European } \\
\text { Union ex-UK }\end{array}$ \\
\hline Terms of trade & -74.0 & -55.3 & -97.1 & -27.9 \\
& $(-1.99)$ & $(-1.05)$ & $(-2.11)$ & $(-2.55)$ \\
\hline Trade in & -.21 & -.85 & 1.55 & .24 \\
services (\$) & $(-0.49)$ & $(-1.40)$ & $(2.94)$ & $(1.95)$ \\
\hline Net foreign & -.1 & -.1 & -.02 & .01 \\
liabilities (\$) & $(-2.76)$ & $(-1.84)$ & $(-0.45)$ & $(1.00)$ \\
\hline Unemployment & $-60,334$ & $-77,283$ & $-51,209$ & $-16,740$ \\
rate $(\%)$ & $(-2.98)$ & $(-2.69)$ & $(-2.05)$ & $(-2.81)$ \\
\hline Adjusted $R^{2}$ & 0.9122 & 0.9028 & 0.5548 & 0.3394 \\
DW & 1.85 & 1.46 & 1.22 & 1.16 \\
\hline
\end{tabular}

Note: $\mathrm{t}$-statistics are reported in parentheses below the estimate to which they refer.

Sources: Air business travel: ABS (Overseas Arrivals and Departures - ABS 3401.0); Commodity trade and trade of services: ABS (Balance of Payments - ABS 5368.0); Unemployment rate: ABS (Labour - ABS 6105.0)

\section{Skilled Labour Flows and Australia's Skill Endowment}

To explore the impact of business travellers on Australia's labour supply, the net outflow of business travellers was related to Australia's stock of skilled labour. This exercise could only be carried out for the period 1986-2000, as information on the stock of labour by skill level is not available for all years. The result is reported in Table 3. Although the metric used to express the flow of business travellers is identical to that used to report the annual inflows of long-term and permanent migrants, a direct comparison between these flows would be misleading as the long-term flow does not account of the average time migrants spend in the host country. This consideration has limited consequences when a country's endowment of skills is viewed as a stock of knowledge that is enhanced by frequent interactions between the country's skilled workers and their overseas colleagues (see, for example, Rogers, 1995). However, it is of critical importance when the country's skill endowment is viewed in terms of skilled labour 'headcount' (discussed below). 
Table 3: Impact of Business Traveller on Australia's Endowment of Skilled Labour, 1986-2000

\begin{tabular}{ccc}
\hline Year & $\begin{array}{c}\text { Net EW from } \\
\text { Air Business Travel }\end{array}$ & $\begin{array}{c}\text { Change in the Stock of Skilled } \\
\text { Labour due to Business Travel } \\
\text { (per cent) }\end{array}$ \\
\hline 1986 & $-7,558$ & -0.43 \\
1987 & $-7,915$ & -0.43 \\
1988 & $-10,620$ & -0.55 \\
1989 & $-13,827$ & -0.70 \\
1990 & $-17,672$ & -0.86 \\
1991 & $-17,781$ & -0.86 \\
1992 & $-20,301$ & -0.98 \\
1993 & $-20,366$ & -0.97 \\
1994 & $-20,577$ & -0.97 \\
1995 & $-19,844$ & -0.93 \\
1996 & $-23,489$ & -0.94 \\
1997 & $-19,784$ & -0.77 \\
1998 & $-16,881$ & -0.65 \\
1999 & $-18,799$ & -0.69 \\
2000 & $-18,358$ & -0.65 \\
\hline Average & & -0.76 \\
\hline
\end{tabular}

Sources: Air Business Travel: ABS (Overseas Arrivals and Departures - ABS 3401.0); Skilled Labour: DIMIA (Statistics section);

The first column lists the net EW from international air business travel calculated in the previous section. This series may be viewed as a measure of the additional international movement of skilled labour between Australia and the rest of the world that remains 'invisible' to measurements of long-term and permanent migration. This interpretation is based on the assumption that international business travellers to and from Australia are skilled, as suggested by empirical findings in other OECD countries (for example, IATS, 1988; Anderson, 2002). In the context of this paper, 'skilled labour' includes only people aged 15 and above in the first three occupational categories of the Australian Standard Classification of Occupations namely, managers and administrators, professionals, and assistant professionals. Skilled manual occupations are excluded. The second column shows the percentage by which the stock of skilled Australian-resident labour would change if the net EW from international business trips were added to it. Australia's endowment of skills is obtained as the sum of its stocks of skilled employed and unemployed labour, as recorded in ABS 3401.0: Overseas Departures and Arrivals.

The calculation on the right column of Table 3 highlights that international air business travel creates a small, but not insignificant, reduction in Australia's endowment of skilled labour. On average, this reduction has been 0.76 per cent during the period 1986-2000. Does this reduction represent a 'real' loss of skilled labour for Australia? 


\section{Some Thoughts on Normative Implications}

The normative implications of a net outflow of business travellers are unclear, as there is no published information on business travellers' motivations. Whether skilled workers undertaking an international trip lend their skills to the country of destination, and if so to what extent, is a challenging issue to understand without reliable measures. A temporary departure from the country of origin due to work applied in the country of destination results in an international transfer of skills there is some evidence that much of this transfer occurs between independently owned firms rather than within transnational companies (for example, Wood, 2001). From Australia's point of view, different conclusions can be drawn depending on which theoretical framework is adopted.

Under the classical interpretation that labour markets are perfectly competitive and labour is an undifferentiated input to production, a business trip abroad reduces Australia's supply of skilled labour though it increases its net export of services. Hence, a business trip would temporarily reduce Australia's domestic skill endowment as well as its GDP, but its GNP would still record the value added generated by the business traveller abroad. As a result, the temporary departure of a skilled worker is not necessarily a loss, though some undesirable consequences for the country of residence have been suggested. For example, Tang and Wood (2000) and Anderson (2002) point out that the income distribution within the country of origin is affected when international business trips are possible. They argue that business travellers enjoy an increased scarcity relative to non-travelling domestic skilled labour, as they can apply their skills across the combined labour markets of countries of origin and destination. An increase in the number of international business travels could raise domestic wage inequality between skilled and unskilled labour in Australia, as well as between travelling and non-travelling skilled labour. If this hypothesis were supported by empirical analysis, policy intervention may be necessary to reduce income disparities.

Under an alternative scenario, whereby labour is a heterogeneous input to production, the stock of skilled workers, as well as the frequency of their interactions matter for a country's ability to generate technological innovation and endogenous economic growth. In fact, new ideas and products not only arise from the number of people engaged in innovative endeavours living in a territory (such as scientists and researchers), but also from their ability to interact and exchange ideas with one another. For example, several studies on innovation highlight that domestic productivity and GDP improve when a country is able to tap into the stock of knowledge that is continuously developed around the world (for example, Dosi et al, 1988; Rogers, 1995). In this context, the use of business trips to access that knowledge has a strategic value. Two issues arise at this point. The first is empirical, and regards the motivation of business trips, on which too little is known. One has to understand whether the net export of skilled labour through business travel implies that Australia is: 
- actively tapping into the stock of knowledge available world-wide to bring it home; or

- $\quad$ selling knowledge abroad at a value below its full potential (see Rogers, 1995 on this point). If this were the case, additional information is necessary to determine whether the exported knowledge is 'old' or whether it is 'new' but it is not adequately valued in Australia.

These considerations lead to different policy recommendations, whose discussion is beyond the scope of this paper.

The second point regards immigration policy and is as follows. If business trips enhance interactions between Australian and foreign skilled labour, and these interactions can potentially strengthen Australia's sources of endogenous growth, then trying to attract skilled settlers to Australia without improving their ability to interact misses a fundamental aspect of how knowledge is generated and benefits society. Namely, that a country can also secure its economic advancement by raising the interactions (or the potential for interactions) between its skilled labour and those of other countries, without having to necessarily raise the permanent headcount of the skilled workers living within its borders.

For example, a country could become more 'attractive' to international skilled labour by having good infrastructure for research, exchanges and trade, transport and communication, or simply an attitude to experiment with and divulge new ideas and products. Doing so does not modify the number of skilled workers permanently living in the country but it can enhance that country's endowment of skills. The existence of international business trips is a sign that the number of workers in a country does not necessarily reflect the amount of 'brains at work' in its economy. One can work on short assignments overseas and still reside in Australia. There may be therefore a risk of mismatch between an immigration policy targeting the domestic headcount of skilled labour and the reality that innovation comes also with interactions among people who never change their residence or citizenship status. The mismatch could make migration policy less effective in its objective of increasing Australia's sources of endogenous economic growth because the number of ideas circulating in Australia and the quality of its stock of skilled labour do not only depend on numbers of bodies. In a border-less world where skilled labour is highly mobile and where many countries compete for it, a 'body-centred' rather than 'brain-centred' immigration policy is still myopic.

\section{Conclusion}

This paper has suggested that migration statistics under-estimate the true extent of international skilled labour movements because they do not account for the flows of workers that thanks to modern means of transportation can move across borders without changing residence. These flows are relevant because of their composition, which is likely to be dominated by skilled labour, magnitude, and increasing substitutability with long-term migration. Australia emerges as a net 
exporter of 'equivalent workers' through business travel. Although information on business trips' motivations are being researched as part of the project related to this paper, some normative implications for Australia were explored. In a world where economic prosperity depends on the stock of ideas and not only on the headcount of skilled labour, an immigration policy focused on attracting 'bodies' rather than 'brains' can be risky, and ineffective. Skilled workers are internationally scarce. Attracting them permanently is highly competitive. Even after their settlement, there is no certainty that they exclusively contribute to the economic growth of the host nation. Business travellers could be an important contributor to Australia's endowment of skills and ought to receive more attention in Australia's migration policies.

\section{References}

Anderson, E. (2002), 'Skilled Worker Mobility and International Inequality', unpublished mimeograph, University of Sussex.

Australian Bureau of Statistics (various issues), Overseas Arrivals and Departures, Catalogue No. 3401.0, ABS, Canberra.

Australian Bureau of Statistics (various issues), Migration, Catalogue No. 3412.0, ABS, Canberra.

Australian Bureau of Statistics (various issues), International Trade in Goods and Services, Catalogue No. 5368.0, ABS, Canberra.

Australian Bureau of Statistics (various issues), Labour Market Statistics, Catalogue No. 6105.0, ABS, Canberra.

Birrell, B., I. Dobson, V. Rapson and T. Smith (2001), Skilled Labour: Gains and Losses, report, Centre for Population and Urban Research, Monash University, Melbourne.

Department of Immigration and Multicultural and Indigenous Affairs (2002), Immigration Update, Commonwealth of Australia, Canberra.

Dornbush, R., S. Fisher, and C. Kearney (1995), Macroeconomics, (Australian Edition) McGraw-Hill, Sydney.

Dosi, G., C. Freeman, R. Nelson, G. Silverberg and L. Soete (eds) (1988), Technical Change and Economic Theory, Maastricht Economic Research Institute on Innovation and Technology, International Federation of Institutes for Advanced Study Research Series, No. 6, Pinter, London and New York.

Gould, J. (1980). 'European Inter-Continental Emigration: The Role of "Diffusion" and "Feedback", Journal of European Economic History 9(2):267-315.

Hugo, G. (2003), 'A New Paradigm of International Migration between the European Union and Australia: Patterns and Implications', Working Paper 62, National Europe Centre, Australian National University, Canberra.

International Air Travel Survey (1988), The European Frequent Business Traveller, European Data and Research Limited, Henley on Thames. 
Moss Kanter, R. (1995), World Class, Simon and Shuster, New York.

Organisation for Economic Co-operation and Development (1994), SOPEMI Report, OECD, Paris.

Ouaked, S. (2002), 'Transatlantic Roundtable on High-skilled Migration and Sending Countries Issues', International Migration 40(4):153-166.

Ohmae, K. (1990), The Borderless World, Harper Business, London.

Piore, M. (1979) Birds of Passage: Migrant Labor Industrial Societies, Cambridge University Press, Cambridge.

Rogers, M. (1995), 'International Knowledge Spill-Overs: A Cross-Country Study', pp. 166-188 in S. Dowrick (ed.), Economic Approaches to Innovation, Edward Elgar Publications, Aldershot, UK and Brookfield, US.

Ruddock, P. (2000). 'Australian Immigration in a "Dot Com" World', Australian Economic Review 33(3):257-261.

Salt, J. (1992), 'Migration Processes Among the Highly Skilled in Europe', International Migration Review 26(2):484-505.

Sassen, S. (1991), The Global City, Princeton University Press, Princeton.

Tang, P. and A. Wood (2000), 'Globalisation, Co-operation and Wage Inequalities', Discussion Paper in Economics No. 66, University of Sussex.

Withers, G. (2003), 'Economic Aspects of Migration: An Australian Overview', Working Paper 65, National Europe Centre, Australian National University, Canberra.

Wolff, E. (2000), 'Human Capital Investment and Economic Growth: Exploring the Macro-Links', Structural Change and Economic Dynamics 11(4):433-472.

Wood, A. (2001), 'Globalisation and Wage Inequalities: A Synthesis of Three Theories', Weltwirtschaflisches Archiv 138(1):54-82.

This paper is part of a project titled 'Skill drain or skill gain? An analysis of air business travel to and from Australia', Special Research Grant UNSWA DOD02 ZECON 0000002003 PS03581. I would like to thank Paul Oslington, Franco Papandrea and two anonymous referees for helpful comments. A very special thanks goes to the Statistics Section of the Department of Immigration and Multicultural and Indigenous Affairs for valuable help with the data on migrants' flows. All errors are mine. 